\title{
Expression of genes $S B P$ and leginsulin in contrasting soybean seed coats
}

\section{Expressão dos genes SBP e leginsulin em tegumentos de sementes de soja contrastantes}

\author{
Carlos André Bahry ${ }^{I}$ Paulo Dejalma Zimmer ${ }^{I I}$
}

\section{ABSTRACT}

Evaluation of differential candidate gene expression in contrasting soybean seeds is an auxiliary tool in the partial elucidation of processes involved in seeds formation, as well as it contributes to the generation of new information that can be used in future research or in the development of $r$ genetic superior constitutions. The aim of this study was to evaluate the expression of two candidate genes, SBP and leginsulin genes, possibly involved in seed quality, in contrasting coats of four soybean genotypes. Two cultivars of yellow soybeans were used, BMX Potência RR and CD 202, and two lines of black soybean, TP and $I A C$. Gene expression was evaluated using $q P C R$ in seven stages of development from seed coats for four genotypes, at 25, 30, 35, 40, 45, 50, and 55 days after anthesis. The design was completely randomized, with three replications. Data were subjected to analysis of variance and means compared by Tukey's test at 5\% probability. SBP and leginsulin gene have higher expression in the early phases of development from seed coats of BMX Potencia RR cultivar, followed by the IAC line. These genotypes are therefore of interest for further research involving these genes.

Key words: gene expression, soybean coats, $q P C R$.

\section{RESUMO}

A avaliação da expressão diferencial de genes candidatos em sementes de soja contrastantes é uma ferramentaauxiliar na elucidação parcial dos processos envolvidos na formação de sementes, além de contribuir para a geração de novas informações que possam ser usadas em futuras pesquisas ou para o desenvolvimento de constituições genéticas superiores. $O$ objetivo do trabalho foi avaliar a expressão de dois genes candidatos, SBP e leginsulin, possivelmente envolvidos com a qualidade das sementes, em tegumentos contrastantes de quatro genótipos de soja. Foram utilizadas duas cultivares de tegumentos amarelos, BMX Potência RR e CD 202, e duas linhagens de tegumentos pretos, TP e IAC. A expressão dos genes foi avaliada pela técnica qPCR, em sete fases de desenvolvimento dos tegumentos para os quatro genótipos, aos 25, 30, 35, 40, 45, 50 e 55 dias após a antese. O delineamento foi o inteiramente casualizado, com três repetições. Os dados foram submetidos à análise de variância e as médias comparadas pelo teste de Tukey, em nível de $5 \%$ de probabilidade. Os genes SBP e leginsulinapresentam maior expressão nas fases iniciais de desenvolvimento dos tegumentos de BMX Potência RR, seguido de IAC, sendo estes genótipos de interesse para novas pesquisas envolvendo estes genes.

Palavras-chave: expressão gênica, tegumentos de soja, $q P C R$.

\section{INTRODUCTION}

After the initial phase of seed formation, young seed coats remain attached to the embryo providing this necessary substances to its full development, from the previous storage in the integument and subsequent transfer to the embryo when it starts to accumulate reserves (BORISJUK et al., 1995; DEJARDIN et al., 1997). Later on, the coat exercises control the seed dormancy and germination processes, in addition to granting protection against biotic and abiotic stress factors (MOÏSE et al., 2005).

Although the importance of the seed coat is recognized, molecular analysis of this structure is relatively recent (MOÏSE et al., 2005). Limited studies have been conducted on the gene expression of soy genotypes with contrasting coat characteristics. However, research indicates that contrasting soy

\footnotetext{
IDepartamento de Agronomia, Universidade Tecnológica Federal do Paraná (UTFPR), Campus de Dois Vizinhos, Estrada para Boa Esperança, KM 04, s/n, 85660-000, Dois Vizinhos, PR, Brasil. E-mail: carlosbahry@utfpr.edu.br. Corresponding author.

IPrograma de Pós-graduação em Ciência e Tecnologia de Sementes, Departamento de Fitotecnia, Faculdade de Agronomia Eliseu Maciel (FAEM), Universidade Federal de Pelotas (UFPel), Pelotas, RS, Brasil.
} 
genotypes for coat characteristics have shown differential expression for genes potentially related to the quality of seeds (MERTZ et al., 2010).

$S B P$ and leginsulin genes are believed to contribute to the quality of soy seeds and indirectly to crops productivity. The SBP gene encodes a sucrose binding protein (transport) found in the plasma membrane of cotyledon cells, leaves, and phloem of ripe vegetables (GRIMES et al., 1992). Furthermore, the $S B P$ gene of soybean has conserved regions identical to vicilin-like protein, indicating a relationship between the $S B P$ gene and storage proteins of seeds (BRAUN et al., 1996; OVERVOORDE et al., 1997; HEIM et al. 2001; WENZEL et al, 2005).

According to VENÂNCIO et al. (2003), the leginsulin gene, initially isolated from the coating of Canavalia ensiformis (Fabaceae), has shown the same molecular mass and amino acid sequence as insulin, which potentially indicates hormonal function in vegetables (YAMAZAKI et al., 2003). BAUMANN et al. (2000) isolated a protein similar to insulin in the developing seeds of Vignia unguiculata, and noticed its potential effect in transporting carbohydrates to the embryo. More recently, some leginsulin-orthologous genes have been widely studied due to their ability to confer defense from pests to seeds during storage (LOUIS et al., 2007; GRESSENT et al., 2011), making them promising bioinsecticides (SILVA et al., 2009).

As mentioned, the $S B P$ and leginsulin genes, present a probable primary function protein coding relating sucrose transport (GRIMES et al, 1992; BAUMANN et al, 2000) to the formation process of soybean seeds. This indicates that, in the case of higher expression of these genes, occurs increased flow of the carbohydrate to said drain, whereas in dicotyledonous sucrose is not broken at the time of tegument transfer to the embryo (BUCKERIDGE et al., 2004). As a result, more carbon reaches the seeds for its formation process elapses occurs.

Besides carbon transport, sucrose can act at the final stage of seed formation as a substance reserve, to be used for the germination process, and serve as the basis for the synthesis of raffinose sugar series, that confer increased tolerance to desiccation, contributing to the maintenance of seed quality (BUCKERIDGE et al., 2004). Thus it reflects the fact that these genes play, possibly plays an important role in the quality of soybean seeds.

In view, the present study aims to assess the expression of both genes during different phases of development of contrasting coats of four soy genotypes.

\section{MATERIALS AND METHODS}

Four soy genotypes with contrasting coat characteristics were used: cultivars 'BMX PotênciaRR' (genetically modified RR1) and 'CD 202' (conventional), both from yellow soybeans; and strains TP and IAC, both from black soybeans.

At anthesis, the flowers were marked, so that all sampled seeds would be in the same development phase. Seven seed collections were performed in five-day intervals $(25,30,35,40,45$, 50 , and $55 \mathrm{~d}$ after anthesis) for each contrasting genotype. Immediately after each collection, the coats were separated from the seeds with the help of sterilized blades. After being separated from seeds, coats for each genotype were stored at $-80^{\circ} \mathrm{C}$ until RNA extraction.

The RNA was extracted using the Concert Plant RNA Reagent kit (Invitrogen ${ }^{\mathrm{TM}}$ ). Extractions were performed separately for each sample time, genotype, and replicate. After extraction, the RNA samples were treated with DNase and their purity and integrity was measured by absorbance analysis (260/280nm) and electrophoresis on a 1\% agarose gel. RNA extraction and cDNA synthesis were performed in triplicates.

Single strand cDNAs were synthesized using SuperScript III ${ }^{\circledR} \quad\left(\right.$ Invitrogen ${ }^{\mathrm{TM}}$ ) reverse transcriptase, as recommended by the manufacturer. In order to perform the cDNA quality test, a semi-quantitative PCR was performed using GoTaq ${ }^{\mathrm{TM}}$ Master Mix (Promega ${ }^{\mathrm{TM}}$ ) cDNA from each sample, water, and $\beta$-actin. The purity and integrity of the cDNA were also measured in order to guarantee the quality of the material used.

The selection of SBP (access no. L06038.1 - NCBI) and leginsulin (access no. D17396.1 - NCBI) genes was based on the broad review regarding the formation of seeds and coats performed by MOÏSE et al. (2005). ACT11(acess no. BW652479.1- NCBI) and SKIP16 (acess no. CD397253.1- NCBI) were used as reference genes. In order to design
the primers for the SBP (sense: GGAAAGCCGTGAAAGGGAAGAAGAA and antisense: CCCGAATTCTGCCACCTTCAGTTT) and leginsulin genes (sense: G C C A C T T C C A C C A T A A T G T T C C C A A and antisense: CCTCGAAAGGTGAACATGCACCATT), the ESTs sequences of the proteins matching the genes were searched in the National Center for Biotechnology Information (NCBI) database. 
Primers were designed using the program Vector NTI Advance 11.0 (Invitrogen $^{\mathrm{TM}}$ ). After relative quantification, the quality of the amplified product was assessed through dissociation curves at the end of the qPCR (BUSTIN et al., 2009), in LightCycler 480 Instrument II (96) (Roche Applied Science ${ }^{\circledR}$ ) equipment using SYBR ${ }^{\circledR}$ Green. The reaction efficiency for each gene was determined by making a curve with serial dilutions of 1:3, 1:30, 1:300, and 1:3000. After the serial dilutions it was possible to calculate the reaction efficiency using the slope of each curve, according to the following formula: $\mathrm{E}=\left|10^{(-1 / \mathrm{slope})}\right|-1$ (ZHAO \& FERNALD, 2005).

At the end of the reaction, the $\mathrm{C}_{\mathrm{q}}$ (Quantification Cycle) was obtained. The relative expression of both genes was calculated based on the amplification efficiency (E) and on the PCR cycle at which an increase in fluorescence above the basal signal was detected.

The gene expression values were normalized to the numbers obtained 25 days after the anthesis of the genotype BMXPotência RR. Results were subjected to analysis of variance (ANOVA), and then the means were compared using Tukey's test at a 5\% probability level.

\section{RESULTS AND DISCUSSION}

The slope (S) and efficiency (E) obtained by serial dilutions and by calculations using the formula $\mathrm{E}$ $=\left|10^{(-1 / \text { slope })}\right|-1($ ZHAO \& FERNALD, 2005) were $\mathrm{S}=$ -2.518 and $\mathrm{E}=1.4954$ for $S B P$ and $\mathrm{S}=-3.609$ and $\mathrm{E}=$ 0.89271 for the leginsulin gene.

The ANOVA results showed that there was an interaction between contrasting genotypes and development phases of the soy seed coatings (days after anthesis) for both genes assessed. Thus, the mean expression data were compared between genotypes for each coat-development stage, and between development stages for each genotype.

SBP

Figure 1 shows gene expression results for the $S B P$ gene, homologous to the one studied by GRIMES et al. (1992). Presence of the $S B P$ gene was observed in all four soy genotypes. In addition, differential expression took place in the development phase of the coats of each genotype assessed, as well as in the comparison between the different soy genotypes.

When analyzing the differential expression between genotypes, it was observed that it was higher at 25 and at 30 DAA (days after anthesis) in cultivar BMX PotênciaRR when compared to the other genotypes, which did not differ from each other. However, in subsequent times, at 35, 40, and 45 DAA, this difference was no longer observed between the four cultivars assessed.

This result is consistent with the observations by FREITAS et al. (2007), who observed that the soy

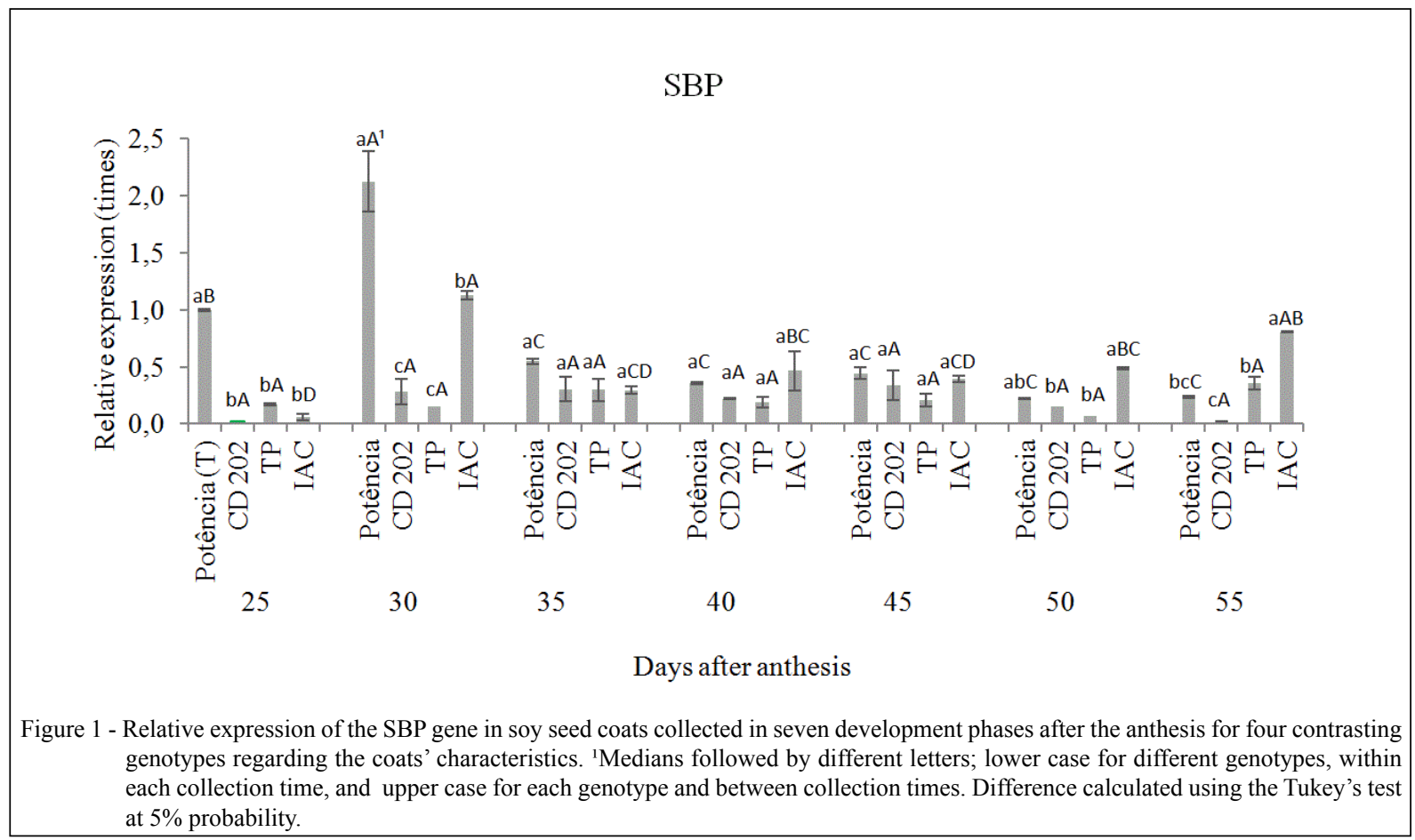

Ciência Rural, v.46, n.10, out, 2016. 
gene GmSBP2 showed higher expression in young tissue and roots, which acted as carbohydrate sinks, mainly during the vegetative phase. In this context, due to the higher expression in the initial stages of seeds development (Figure 1), the gene product probably acts by transporting sucrose (OVERVOORDE et al., 1997), targeting the appropriate development stage during seed formation, being this one of the functions attributed to the coats of soy seeds (WEBER et al., 2005).

Furthermore, when comparing the soy genotypes with contrasting coats, at 50 DAA, the highest gene expression occurred in the genotypes IAC and BMXPotênciaRR. Conversely, at 55 DAA, the IAC genotype showed higher expression of the gene in its coats compared to the others; the lowest expression was observed in cultivar CD 202 (Figure 1).

The $S B P$ protein has been credited with important seed functions by ROCHA et al. (2007). According to the authors, due to its high stability, the protein can improve tolerance to desiccation during the maturation of the seeds.

When analyzing the expression of the $S B P$ gene in the different development phases of coats for each genotype, it was observed that for BMX PotênciaRR, the gene was expressed more often at 30 DAA, followed by 25 DAA, that is, in the initial formation and seed-filling phases. At 35, $40,45,50$, and 55 DAA, the expression of the gene did not change between the development phases. For genotypes CD 202 and TP, the level of expression of the gene did not change between the coats' development phases (Figure 1).

The higher expression observed in the initial development phases of the coats in cultivar 'BMX PotênciaRR' might be related to the potential function performed by the protein encoded by the $S B P$ gene, which transports sucrose, acting more specifically in sinks, as observed by GRIMES et al. (1992).

It can be assumed that highest expression of $S B P$ for the IAC genotype occurred at 30 DAA, though it was not significantly higher than expression at 55 DAA. The next highest expression, at 55 DAA, was not significantly higher than 40,45 , or 50 DAA. The lowest expression level for the gene in this strain occurred at 25, 35, and 45 DAA (Figure 1).

When inferring the potential relationships between this genegroup and the genes encoding storage proteins, the data here by obtained regarding the expression pattern for the $S B P$ gene is consistent with the studies performed by DHAUBHADEL et al. (2007) on soy and DUAN \& SUN (2005) on rice.
Leginsulin

The leginsulin gene (insulin binding protein) was described according to WATANABE et al. (1994), who assessed its level of expression in contrasting coat genotype coats, as can be observed in the sequence.

When comparing the expression of the leginsulin gene in different genotypes, it was observed that it was similar for all four materials tested at 25 days after anthesis (DAA). At 30 DAA, higher expression of the gene was observed in cultivar 'BMX PotênciaRR', followed by IAC, CD 202, and TP, showing differences for all genotypes. For the TP strain, a higher gene expression was observed at 35 DAA; it did not differ between the other development phases of the coat (Figure 2).

YAMAZAKI et al. (2003) indicated a potential hormonal function for the leginsulin gene, which would interact with a 43-kDa protein to generate cell signal transduction due to phosphorylation activity of the protein. This is consistent with the results of WATANABE et al. (1994).

At 40, 45, and 50 DAA, no difference was observed in the expression of the leginsulin gene among the genotypes studied. However, at 55 DAA, the CD 202 genotype expressed more leginsulin compared to the others, which did not differ from each other.

When comparing the expression of the leginsulin gene for each different genotype in the different development phases of the coats, the cultivar BMX PotênciaRR showed higher expression at $30 \mathrm{DAA}$; there was no difference regarding the expression in the other phases. A similar situation was observed for the IAC strain.

In the days following anthesis, the embryo is in full development, requiring a large input of photoassimilates. BAUMANN et al. (2000) isolated a protein similar to insulin in developing seeds of Vignia unguiculata, and observed its potential participation in carbohydrate transport to the embryo.

The pattern of expression verified in genotype CD 202 showed different behavior when compared to the others, with higher expression of leginsulin gene observed in two phases, at 30 DAA and 55 DAA, which did not differ from each other (Figure 2). Regarding genotype TP, the highest expression of the leginsulin gene occurred at 30 DAA, and no difference was observed between the other development phases of the coats.

Currently some orthologs of the leginsulin gene have been widely studied, such as $P A 1 b$ in peas, which protects against pests, such as Sitophilus sp. 


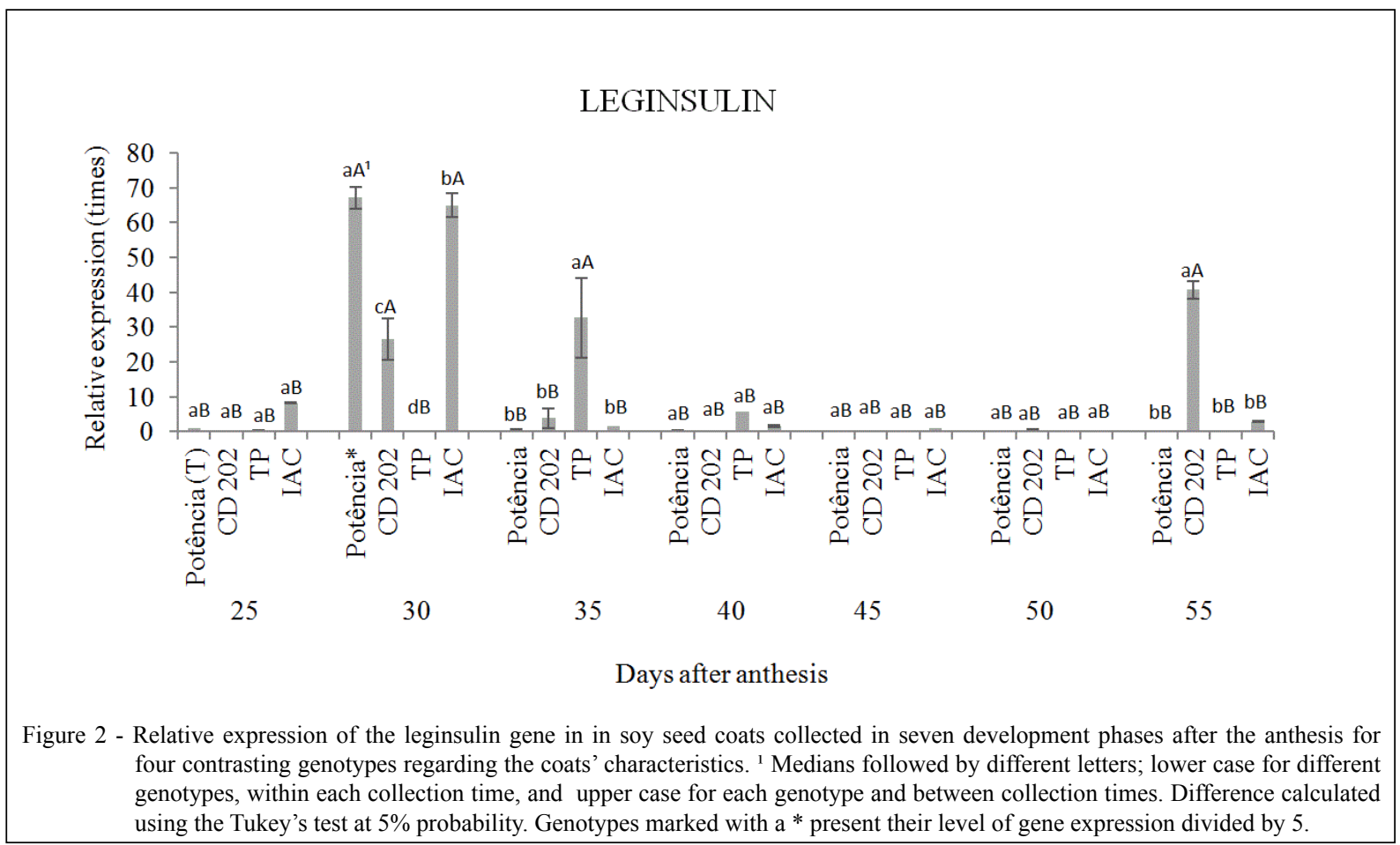

and some species of aphids, in stored seeds (LOUIS et al., 2007; GRESSENT et al., 2011); it is therefore considered a promising bioinsecticide (SILVA et al., 2009). Combined with these studies, the results obtained here open a new array of possibilities for further research in order to clarify the real function of these genes in soy seeds.

\section{CONCLUSION}

$S B P$ and leginsulin genes showed higher expression in the initial development phases of coats for BMX PotênciaRR, followed by IAC; these genotypes are, therefore, interesting for further studies on these genes.

\section{ACKNOWLEDGEMENTS}

We thank the Conselho Nacional de Desenvolvimento Científico e Tecnológico (CNPq), Fundação de Amparo à Pesquisa do Estado do Rio Grande do Sul (FAPERGS), and Coordenação de Aperfeiçoamento de Pessoal de Nível Superior (CAPES) for granting a scholarship and other funding toward this research.

\section{REFERENCES}

BAUMANN, C.A. et al. CAP defines a second signalling pathway required for insulin-stimulated glucose transport. Nature, v.407, p.202-207, 2000. Available from: $<$ http://libgen.org/scimag/index. php?s $=\&$ siteid $=0028-0836$ and $1476-4679 \& \mathrm{v}=407 \& \mathrm{i}=6801>$. Accessed: Jan. 20, 2014. doi: 10.103835025089.
BORISJUK, L. et al. Embryogenesis of V. faba histodifferentiation in relation to starch and storage protein synthesis. Journal of Plant Physiology, v.147, n.2, p.203-218, 1995. Available from: <http://ac.els-cdn.com/ S0176161711815075/1-s2.0-S0176161711815075-main.pdf? tid $=43 \mathrm{cf} 37 \mathrm{ce}-\mathrm{fc} 12-11 \mathrm{e} 5-\mathrm{b} 053-00000 \mathrm{aacb} 360 \& \mathrm{acdnat}=145 \overline{9}$ 959288_572dbf4e3bac607016b0a638002e 0cef>. Accessed: Apr. 01, 2016. doi: 10.1016/S0176-1617(11)81507-5.

BRAUN, H. et al. A vicilin-like seed protein of cycads: similarity to sucrose binding proteins. Plant Molecular Biology, v.31, n.1, p.35-44, 1996. Available from: <http://download.springer. com/static/pdf/906/art\%253A10.1007\%252FBF00020604. pdf?originUrl=http $\% 3 \mathrm{~A} \% 2 \mathrm{~F} \% 2 \mathrm{Flink}$.springer.com $\% 2 \mathrm{Farticle}$ $\% 2 \mathrm{~F} 10.1007 \% 2 \mathrm{FBF} 00020604 \&$ token $2=\exp =1459961049 \sim \mathrm{acl}$ $=\% 2 \mathrm{Fstatic} \% 2 \mathrm{Fpdf} \% 2 \mathrm{~F} 906 \% 2 \mathrm{Fart} \% 25253 \mathrm{~A} 10.1007 \% 25252 \mathrm{~F}$ BF00020604.pdf\%3ForiginUrl\%3Dhttp\%253A\%252F\%252Fli nk.springer.com\%252Farticle $\% 252 \mathrm{~F} 10.1007 \% 252 \mathrm{FBF} 00020604$ * $\sim \mathrm{hmac}=6 \mathrm{e} 13 \mathrm{db} 3527644 \mathrm{ee} 7 \mathrm{edc} 70 \mathrm{cdd} 4734 \mathrm{af9fba97f8497e34f53}$ 88f2b251119c51bca>. Accessed: Apr. 01, 2016.

BUCKERIDGE, M. S. et al. Acúmulo de reservas. In: GUI FERREIRA, A.; BORGHETTI, F. (Orgs). Germinação: do básico ao aplicado. Porto Alegre: Artmed. 2004. p.31-50.

BUSTIN, S.A. et al. The MIQE guidelines: minimum information for publication of quantitative real time PCR experiments. Clinical Chemistry, v.55, n.4, p.611-622, 2009. Available from: <http:// www.clinchem.org/content $/ 55 / 4 / 611$.full.pdf $+\mathrm{html}>$. Accessed: Jan. 17, 2014. doi: 10.1373/clinchem.2008.112797.

DHAUBHADEL, S. et al. Transcriptome analysis reveals a critical role of CHS7 and CHS8 genes for isoflavonoid synthesis in soybean seeds. Plant Physiology, v.143, n.1, p.326-338, 2007. Available from: <http:// www.ncbi.nlm.nih.gov/pmc/articles/PMC1761968/pdf/pp1430326. pdf $>$. Accessed: Jan. 12, 2014. doi: /10.1104/pp.106.086306.

Ciência Rural, v.46, n.10, out, 2016. 
DÉJARDIN, A. et al. Purification, characterization and physiological role of sucrose synthase in the pea seed coat (Pisum sativum L.). Planta, v.201, p.128-137, 1997. Available from: <http://download.springer.com/ static/pdf/448/art\%253 A 10.1007\%252FBF01007697. pdf?originUrl $=$ http $\% 3 \mathrm{~A} \% 2 \mathrm{~F} \% 2 \mathrm{Flink}$.springer.com $\% 2 \mathrm{Farticle}$ $\% 2 \mathrm{~F} 10.1007 \% 2 \mathrm{FBF} 01007697 \&$ token $2=\exp =1459961386 \sim \mathrm{acl}$ $=\% 2$ Fstatic $\% 2 F p d f \% 2 F 448 \% 2$ Fart $\% 25253 \mathrm{~A} 10.1007 \% 25252 \mathrm{~F}$ BF01007697.pdf\%3ForiginUrl\%3Dhttp\%253A\%252F\%252Fli nk.springer.com $\% 252$ Farticle $\% 252$ F $10.1007 \% 252$ FBF 01007697 $* \sim \mathrm{hmac}=\mathrm{b} 78 \mathrm{~b} 5 \mathrm{f} 33608098636 \mathrm{e} 38 \mathrm{a} 62306 \mathrm{eef} 7818 \mathrm{ee} 159 \mathrm{ecc} 3 \mathrm{~b} 1812$ 5109871d1e18545b8>. Accessed: Mar. 28, 2016.

DUAN, M.; SUN, S.S.M. Profiling the expression of genes controlling rice grain quality. Plant Molecular Biology, v.59, n.1, p.165-178, 2005. Available from: <http://libgen.org/scimag/?s=Pr ofiling+the+expression + of + genes + controlling + Rice + grain + quali ty. $+\&$ siteid $=\& v=\& i=\& p=\&$ redirect $=1>$. Accessed: Jan. 12, 2014. doi: $10.1007 / \mathrm{S} 11103-004-7507-3$.

FREITAS, R.L. et al. Distinct repressing modules on the distal region of the SBP2 promoter contribute to its vascular tissuespecific expression in different vegetative organs. Plant Molecular Biology, v.65, n.5, p.603-614, 2007.Available from: $<$ http://libgen. $\mathrm{org} / \mathrm{scimag} /$ ?s=Distinct + repressing + modules + on + the + distal + reg ion + of + the + SBP $2+$ promoter + contribute + to + its + vascular + tissuespecific + expression + in + different + vegetative + organs. $+\&$ siteid $=\&$ $\mathrm{v}=\& \mathrm{i}=\& \mathrm{p}=\&$ redirect $=1>$. Accessed: Jan. 15, 2014. doi: 10.1007/ S11103-007-9225-0.

GRESSENT, F. et al. Pea Albumin 1 Subunit b (PA1b), a promising bioinsecticide of plant origin. Toxins, v.3, n.1, p.1502-1517, 2011. Available from: <http://www.ncbi.nlm.nih.gov/pmc/articles/ PMC3268454/pdf/toxins-03-01502.pdf>. Accessed: Jan. 15, 2014. doi: $10.3390 /$ toxins3121502>.

GRIMES, H.D. et al. A 62-kD sucrose binding protein is expressed and localized in tissues actively engaged in sucrose transport. Plant Cell, v.4, n.12, p.1561-1574, 1992. Available from: <http:// www.ncbi.nlm.nih.gov/pmc/articles/PMC160242/pdf/041561. pdf>. Accessed: Jan. 12, 2014.

LOUIS, S. et al. Broad screening of the legume family for variability in seed insecticidal activities and for the occurrence of the Alb-like knottin peptide entomotoxins. Phytochemistry, v.68, n.4, p.521-535, 2007. Available from: <http://libgen.org/sc $\mathrm{imag} /$ ? $\mathrm{s}=$ Broad + screening + of + the + legume + family + for + variabil ity + in + seed + insecticidal + activities + and + for + the + occurrence $+o$ $\mathrm{f}+$ the $+\mathrm{A} 1 \mathrm{~b}-$ like + knottin + peptide + entomotoxins. $+\&$ siteid $=\& \mathrm{v}=$ $\& \mathrm{i}=\& \mathrm{p}=\&$ redirect $=1>$. Accessed: Jan. 18, 2014. doi: 10.1016/j. phytochem.2006.11.032.

MERTZ, L.M. et al.cDNA-AFLP analyses between black and yellow soybean seed coats. Seed Science \& Technology, v.38, p.88-95, 2010.Available from: <http://www.ingentaconnect.com/ content/ista/sst/2010/00000038/00000001/art00009>. Accessed: Jan. 10, 2014.

MOÏSE, J.A. et al. Seed coats: structure, development, composition, and biotechnology. In Vitro Cellular \& Developmental Biology - Plant, v.41, n.5, p.620-644, 2005. Available from: $<$ http:// libgen.org/scimag/index.php?s $=\&$ siteid $=S L \_11627 \& v=41 \& \mathrm{i}=5>$. Accessed: Jan. 29, 2014. doi: 10.1079/ivp2005686.
OVERVOORDE, P.J. et al. A plasma membrane sucrosebinding protein that mediates sucrose uptake shares structural and sequence similarity with seed storage proteins but remains functionally distinct. Journal of Biological Chemistry, v.272, n.25, p.15.898-15.904, 1997.Available from: <http://www.jbc.org/ content/272/25/15898.full.pdf + html $>$. Accessed: Jan. 10, 2014. doi: $10.1074 /$ jbc. 272.25 .15898 .

ROCHA, C.S. et al. Expression of the sucrose binding protein from soybean: renaturation and stability of the recombinant protein. Phytochemistry, v.68, n.6, p.802-810, 2007. Available from: $<$ http://libgen.org/scimag/?s=Expression + of + the+ + sucrose + bindi $\mathrm{ng}+$ protein + from + soybean $\% 3 \mathrm{~A}+$ renaturation + and + stability + of + the + recombinant + protein.$+\&$ siteid $=\& v=\& i=\& p=\&$ redirect $=1>$. Accessed: Jan. 15, 2014. doi: 10.1016/j.phytochem.2006.11.036.

SILVA, P. da et al. A folded and functional synthetic PA1b: an interlocked entomotoxic miniprotein. Peptide Science, v.92, n.5, p.436-444, 2009. Available from: <http://libgen.org/scimag/?s= + folded+and+functional+synthetic + PA1b $\% 3 \mathrm{~A}+\mathrm{an}+$ interlocked + entomotoxic + miniprotein.$+\&$ siteid $=\& \mathrm{v}=\& \mathrm{i}=\& \mathrm{p}=\&$ redirect $=1>$. Accessed: Jan. 25, 2014. doi: 10.1002/bip.21217.

VENÂNCIO, T.M. et al. A protein with amino acid sequence homology to bovine insulin is present in the legume Vigna unguiculata (Cowpea). Brazilian Journal of Medical \& Biological Research, v.36, p.1167-1173, 2003. Available from: $<$ http://www.scielo.br/pdf/bjmbr/v36n9/4846.pdf $>$.Accessed: Jan. 20, 2014. doi: 10.1590/S0100-879X2003000900004.

WATANABE, Y. et al. A peptide that stimulates phosphorylation of the plant insulin-binding protein isolation, primary structure and cDNA cloning. European Journal of Biochemistry, v.224, p.167-172, 1994. Available from: <http://onlinelibrary.wiley.com/ doi/10.1111/j.1432-1033.1994.tb20008.x/pdf>. Accessed: Jan. 25, 2014. doi: 10.1111/j.1432-1033.1994.tb20008.x.

WEBER, H. et al. Molecular physiology of legume seed development. Annual Review of Plant Biology, v.56, n.1, p.253-279, 2005. Available from: <http://libgen. org/scimag/index.php?s=\&siteid $=1040-2519$ and $1545-$ 2123\&v $=56 \& \mathrm{i}=1>$. Accessed: Jan. 23, 2014. doi: 10.1146/ annurev.arplant.56.032604.144201.

WENZEL, D. et al. The cargo in vacuolar storage protein transport vesicles is stratified. Traffic, v.6, n.1, p.45-55, 2005. Available from: <http://onlinelibrary.wiley.com/doi/10.1111/ j.1600-0854.2004.00243.x/pdf>. Accessed: Jan. 15, 2014. doi: 10.1111/j.1600-0854.2004.00243.x.

YAMAZAKI, T. et al. A possible physiological function and the tertiary structure of a 4-kDa peptide in legumes. European Journal of Biochemistry, v.270, n.6, p.1269-1276, 2003. Available from: <http://onlinelibrary.wiley.com/doi/10.1046/ j.1432-1033.2003.03489.x/pdf>. Accessed: Jan. 25, 2014. doi: 10.1046/j.1432-1033.2003.03489.x.

ZHAO, S.; FERNALD, R.D. Comprehensive algorithm for quantitative real-time polymerase chain reaction. Journal of Computational Biology, v.12, n.8, p.1047-1064, 2005. Available from: <http:/www.ncbi.nlm.nih.gov/pmc/articles/PMC2716216/ pdf/nihms114913.pdf. Accessed: Jan. 10, 2014. doi: 10.1089/ cmb.2005.12.1047. 